\title{
The Neurosteroid Tetrahydroprogesterone Attenuates the Endocrine Response to Stress and Exerts Glucocorticoid-like Effects on Vasopressin Gene Transcription in the Rat Hypothalamus
}

\author{
V. K. Patchev, M.D., Ph.D., A. H. S. Hassan, B.V.Sc., Ph.D., F. Holsboer, M.D., Ph.D.,
} and O. F. X. Almeida, Ph.D.

The neurosteroid tetrahydroprogesterone ( $5 \alpha$-pregnan-3 $\alpha$ ol-20-one, allopregnanolone, THP), has been previously shown to counteract the anxiogenic effects of corticotropinreleasing hormone (CRH) and to interfere with noradrenergic and corticosteroid-mediated regulation of $\mathrm{CRH}$ release and gene transcription. Those observations indicated that, besides its sedative and analgesic activity, THP may also affect the neuroendocrine response to stress in a mode resembling that of corticosteroids. To examine this possibility, we compared the ability of THP, its precursor progesterone $\left(\mathrm{P}_{4}\right)$, and the glucocorticoids dexamethasone (DEX) and corticosterone (CORT) to influence the pituitary-adrenal response to acute emotional stress and the adrenalectomy-induced increase in the gene transcription of the stress-related peptide arginine vasopressin $(A V P)$ and of corticosteroid receptors (MR and $G R)$ in the brain. Pretreatment of rats with a single dose of THP or $\mathrm{P}_{4}(50 \mu \mathrm{g} / \mathrm{kg})$ significantly attenuated the elevation of plasma adrenocorticotropin (ACTH) and serum corticosterone after emotional stress; both steroids were, however, less potent than a similar dose of DEX.
Administration of $1 \mathrm{mg}$ of THP, CORT, or $\mathrm{P}_{4}$ to adrenalectomized $(A D X)$ rats attenuated the increase in AVP mRNA levels in the ventromedial subdivision of the hypothalamic paraventricular nucleus ( $P V N$ ), as compared with vehicle-treated ADX rats. However, whereas CORT and $\mathrm{P}_{4}$ influenced the ADX-induced increase in the transcription of both types of corticosteroid receptors in the hippocampus, these were unaffected by THP. In contrast to the glucocorticoids, THP and $\mathrm{P}_{4}$ failed to decrease plasma ACTH levels in rats deprived of endogenous steroids. These results demonstrate that the neurosteroid THP and its precursor $\mathrm{P}_{4}$ resemble glucocorticoids in their suppression of the pituitary-adrenal response to emotional stress; however, THP influences the transcription of glucocorticoid-responsive genes in brain structures involved in the regulation of the hypothalamo-pituitaryadrenal system in a fashion that is quite distinct from that obtained with glucocorticoids. (c) 1996 American College of Neuropsychopharmacology

[Neuropsychopharmacology 15:533-540, 1996]
From the Department of Neuroendocrinology, Max Planck Institute of Psychiatry, Clinical Institute, Munich, Germany.

Address correspondence to: V. K. Patchev, Department of Neuroendocrinology, Max Planck Institute of Psychiatry, Clinical Institute, Kraepelinstr. 2, 80804 Munich, Germany. E-mail: patchev @mpipsykl.mpg.de

Received January 12, 1996; revised April 4, 1996; accepted April $11,1996$.
KEY WORDS: Neurosteroids; Progesterone; Glucocorticoids; Vasopressin; Corticosteroid receptors; Stress

The ring-A-reduced metabolite of progesterone, $5 \alpha$ pregnan-3 $\alpha$-ol-20-one (allopregnanolone, tetrahydroprogesterone; THP), is synthesized in a number of endocrine tissues as well as in the brain. This neurosteroid is 
a potent agonist of the $\mathrm{GABA}_{\mathrm{A}}$ receptor complex and displays significant sedative-hypnotic and analgesic activities (Majewska et al. 1986; Kavaliers and Wiebe 1987; Bitran et al. 1991; Paul and Purdy 1992). The observation that the synthesis of THP and other $3 \alpha$-hydroxy-pregnan derivatives in the brain is increased after acute stress led to the suggestion that these steroids may act as endogenous stress-protective compounds (Purdy et al. 1991). Indeed, we recently demonstrated that THP counteracts the anxiogenic activity of corticotropin-releasing hormone $(\mathrm{CRH})$, and attenuates methoxamine-stimulated CRH release in vitro in a dose-dependent fashion (Patchev et al. 1994a). On the one hand, the observation that THP exerts actions that have a rapid onset is consistent with the widely held view that membrane receptors (e.g., $\mathrm{GABA}_{\mathrm{A}}$ receptors) may be the principal mediators of neurosteroid action (Puia et al. 1990; Baulieu 1992). On the other hand, our previous studies (Patchev et al. 1994a), and those by Rupprecht et al. (1993), demonstrated that THP may also modulate gene expression in neurons in vivo and in vitro, although the mechanism(s) that mediate these "genomic" effects of neurosteroids remain to be elucidated.

$\mathrm{CRH}$ plays a major, but not singular, role in activating the hypothalamo-pituitary-adrenal (HPA) system under physiological conditions (e.g., stress), as well as upon removal of glucocorticoid-mediated negative feedback (e.g., adrenalectomy, ADX). The nonapeptide arginine vasopressin (AVP), principally that originating within the parvocellular subdivision of the hypothalamic paraventricular nucleus (PVN), synergizes with CRH to maximize the "hypothalamic drive" upon pituitary corticotrophs (Gillies et al. 1982, Antoni 1993). The synthesis and secretion of CRH and PVN-derived AVP have previously been shown to be subject to negative regulation by corticosteroids, as well as by the synthetic glucocorticoid dexamethasone (DEX) (Davis et al. 1986; Sawchenko 1987; Sapolsky et al. 1990; Sawchenko et al. 1992). These effects are mediated by corticosteroid receptors in the corresponding peptidergic neurons, as well as in extrahypothalamic regions, such as the hippocampus. The synthesis and binding characteristics of the two types of corticosteroid receptors in the hippocampus - mineralocorticoid receptors (MR) and glucocorticoid receptors (GR) - are also subject to regulation by adrenal steroids (Chao et al. 1989; Reul et al. 1989; Spencer et al. 1991; Patchev et al. 1994b; Castrén et al. 1995). Their exceptional abundance in the hippocampus confers this structure with a central role in the regulation of the HPA axis (McEwen and Brinton 1987; Herman et al. 1989). In view of our earlier finding that THP inhibits the synthesis and release of $\mathrm{CRH}$ in much the same way as corticosteroids, the question arose as to whether THP modifies the pituitary-adrenal response to stress, and whether the transcriptional effects of this neurosteroid extend to other compartments of the HPA system. At the same time, the suggestion that, at least, some of the neurotropic effects of THP may be mediated through progesterone receptors (Rupprecht et al. 1993), led us to compare the effects of THP with those of its natural precursor, progesterone $\left(\mathrm{P}_{4}\right)$. Briefly, we examined the ability of THP, $\mathrm{P}_{4}$, and glucocorticoids to attenuate stress-induced activation of pituitary-adrenal secretions, and to influence the regulation of glucocorticoid-responsive genes in the rat brain. Because gene transcription of AVP in parvocellular neurons, located in the medial subdivision of the PVN, as well as that of corticosteroid receptors in the hippocampus, is regulated by glucocorticoids (Davis et al. 1986; Patchev et al. 1994b), we used the paradigm of ADX-induced increases in AVP, MR, and GR mRNA levels in these anatomical structures to compare the transcriptional effects of the three classes of steroids. To eliminate potential interference by gonad-derived steroids, we additionally gonadectomized (GDX) all experimental subjects in the gene expression studies.

\section{MATERIALS AND METHODS}

Adult male Wistar rats (MPI, Martinsried, Germany) were housed in groups of five under controlled ambient temperature $\left(24^{\circ} \mathrm{C}\right)$ and illumination $(12: 12$ hours, lights on from 07:00 to 19:00 hours). The animals had free access to food and water. After 1 week of acclimation, rats were intraperitoneally injected with either THP, DEX, or $\mathrm{P}_{4}$ (Steraloids; Wilton, NJ) at a dose of $50 \mu \mathrm{g} / \mathrm{kg}$, or with vehicle (37\% aqueous solution of 2-isopropyl- $\beta$-cyclodextrin; RBI, Natick, MA). Thirty minutes thereafter, the animals were exposed for 2 minutes to intermittent air-puffs of 10 to 15 seconds each, delivered by a hairdryer. The rats were killed by decapitation 30 minutes after termination of the stress procedure, and plasma and serum from trunk blood were collected for measurement of ACTH and CORT, respectively, by specific radioimmunoassays (ICN Biomedicals; Costa Mesa, CA). The experiment was done between 08:00 and 10:00 hours, i.e., during the diurnal trough in adrenocortical function.

Separate groups of rats were bilaterally adrenalectomized and castrated (ADX/GDX) during a single session under barbiturate anesthesia (Brevimytal; Lilly, Bad Homburg, Germany); these animals were supplied with physiological saline as drinking fluid. Sham-operated controls only received skin incisions. Immediately after recovery from anesthesia, randomly selected groups of ADX-GDX rats were subcutaneously injected with either $0.2 \mathrm{ml}$ of vehicle (corn oil) or $1 \mathrm{mg}$ of THP, CORT, or $\mathrm{P}_{4}$. Twenty-four hours after surgery and steroid treatment (10:00 to 12:00 hours), rats were killed by decapitation, their brains rapidly removed, snap-frozen by immersion in prechilled isopentane, and stored at $-70^{\circ} \mathrm{C}$ until sectioning. Plasma from trunk blood was 
collected for the determination of ACTH. The experiments were conducted in compliance with national regulations on animal welfare.

Steady-state levels of mRNAs encoding AVP and corticosteroid receptors were assessed by in situ hybridization histochemistry. Coronal cryosections (14 $\mu \mathrm{m})$ from the brain regions of interest were thawmounted on gelatin-coated slides and air-dried. Fixation, acidification, and delipidation were performed as described elsewhere (Brady et al. 1990; Whitfield et al. 1990). A commercially synthesized oligonucleotide 48mer probe (MWG-Biotech; Ebersberg, Germany), complementary to nucleotides $1009-1056$ of the rat AVP gene (Ivell and Richter 1984), was used for the detection of transcripts encoding AVP. The probe was labeled with $\left[{ }^{35}\right.$ S]dATP (NEN; Boston, MA) by terminal deoxynucleotidyl transferase (Gibco BRL; Bethesda, MD). The plasmids containing the 513 nucleotides encoding the carboxy-terminal 25 amino acids and a part of the 3 '-untranslated region of the rat MR (Arriza et al. 1988), and nucleotides $81-528$ of the rat GR sequence (Miesfeld et al. 1986) were donated by Dr. L. Brady (NIMH; Bethesda, MD). Upon linearization with HindIII or EcoRI, respectively, $\left[{ }^{35} \mathrm{~S}\right] \mathrm{dUTP}$-labeled antisense cRNA probes were produced by SP6-initiated in vitro transcription (Promega Biotech; Madison, WI). Sections of the areas of interest were hybridized and stringencywashed according to previously published protocols (Brady et al. 1990; Whitfield et al. 1990), and apposed to Hyperfilm $\beta$-max (Amersham; Braunschweig, Germany). In all cases, hybridization with radioactively labeled sense probes was used to verify the specificity of hybridization signals.

Optical densities of the autoradiographic images of the PVN and hippocampal subdivisions $\left(\mathrm{CA}_{2}\right.$ for $\mathrm{MR}$ and $\mathrm{CA}_{1}$ for $\mathrm{GR}$ ) were quantified with the Macintoshbased image analysis software NIH IMAGE 1.52 (Research Services Branch, NIMH; Bethesda MD). A thirdorder polynomial equation was used to convert optical densities to $\mu \mathrm{Ci} / \mathrm{g}$ tissue, based on readings from co-exposed radioactive standards. The medial subdivision of the PVN in film images (Figure $1 \mathrm{~A}$ ) was defined according to Sawchenko and Swanson (1983). In addition, changes in AVP gene expression in this region were assessed by determining the number of neurons displaying AVP transcripts in a rectangular field with constant dimensions in hybridized sections coated with K.5emulsion (Ilford; Mobberley, UK) and counter-stained with Giemsa (Figure $1 \mathrm{~B}$ ). Hybridization signals for AVP in the supraoptic nucleus and GR in the PVN were measured by densitometry of film autoradiograms, as described above. For each animal, four measurements were made on two adjacent brain sections and averaged to obtain individual means. Group means were compared by one-way-ANOVA; where appropriate, the Dunnett test was applied post hoc to reveal the signifi- cance of differences between steroid-treated and control groups $(p<.05)$. Results are presented as mean \pm SEM of four to five individuals per group.

\section{RESULTS}

Thirty minutes after exposure to intermittent air puffs, plasma $\mathrm{ACTH}$, and serum CORT levels in vehicletreated rats were significantly increased above those measured in nonstressed animals $(110 \pm 14 \mathrm{pg} / \mathrm{ml}$ and $44 \pm 15 \mathrm{ng} / \mathrm{ml}$, respectively). Single injections of $50 \mu \mathrm{g} /$ $\mathrm{kg}$ of THP or $\mathrm{P}_{4}$ before emotional stress significantly at-
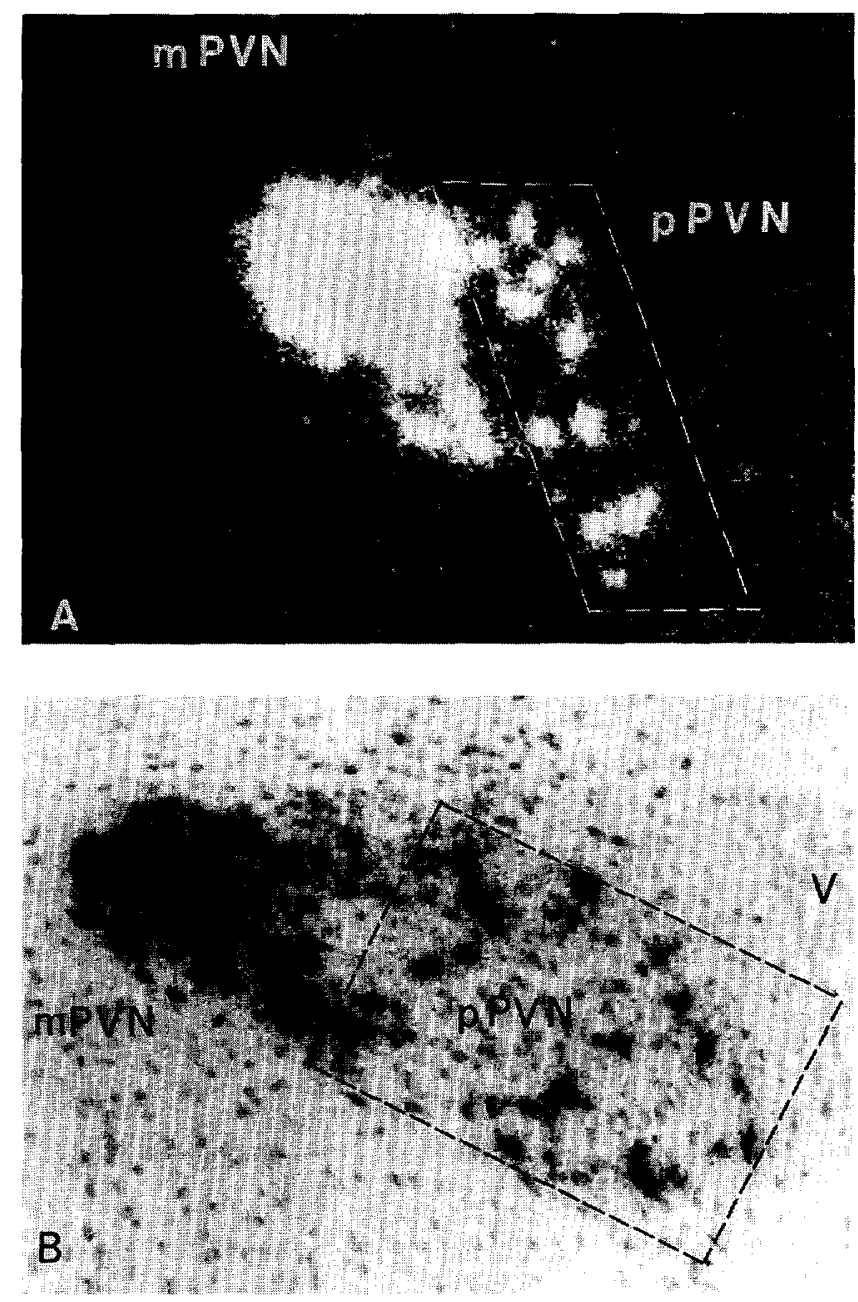

Figure 1. (A): Dark-field microphotograph of an in situ hybridization for AVP mRNA in the PVN of an adrenalectomized rat. The delineated ventromedial subdivision ( $P P V N)$, containing mostly parvocellular, glucocorticoid-sensitive neurons represents area used for densitometric readings. (B): High-magnification bright-field microphotograph of an emulsion-coated and Giemsa-counter-stained section through the PVN. The rectangle depicts the area within which the number of AVP-expressing neurons was determined; $\mathrm{mPVN}$ denotes magnocellular AVP-expressing neurons, $\mathrm{V}$ indicates the third ventricle. 
tenuated the stress-induced increase in $\mathrm{ACTH}$ and CORT. Pretreatment with DEX virtually abolished the pituitary-adrenal secretory response to stress (Figure 2).

Twenty-four hours after removal of the adrenals and gonads (ADX/GDX), the hybridization signal for AVP mRNA and the number of AVP-expressing cells in the ventromedial subdivision of the PVN were significantly increased in vehicle-injected rats as compared to shamoperated controls. Administration of $1 \mathrm{mg}$ of THP, CORT, or $\mathrm{P}_{4}$ at the time of surgery prevented the increase in these parameters within the following 24 hours (Figure 3). Neither ADX/GDX nor any of the steroid treatments used influenced AVP mRNA levels in the supraoptic nucleus (data not shown).

Hybridization signal for MR mRNA in the hippocampus was significantly stronger in the subfields $\mathrm{CA}_{1-2}$ and the dentate gyrus; however, steroid-induced changes in MR mRNA were not obviously related to any particular anatomical subdivision. Removal of the adrenals and gonads significantly increased MR mRNA levels; whereas this elevation was significantly attenuated in CORT- and $\mathrm{P}_{4}$-treated rats, THP administration failed to influence ADX/GDX-induced changes in MR gene transcription (Figure 4).

Hybridization signal for GR mRNA in the hippocampus was predominantly confined to the $\mathrm{CA}_{1}$ subfield and dentate gyrus. Adrenalectomy/castration resulted in a significant increase in GR mRNA levels, which was virtually abolished by CORT and $\mathrm{P}_{4}$ administration. THP treatment failed to produce any significant effect on ADX/GDX-elevated GR mRNA levels (Figure 4). None of the treatments used altered GR mRNA levels in the PVN (data not shown).

Plasma ACTH levels were significantly elevated after removal of the steroid-producing glands (552 \pm 38 $\mathrm{pg} / \mathrm{ml}$ vs $178 \pm 58 \mathrm{pg} / \mathrm{ml}$ in sham-operated rats). This increase was significantly attenuated by CORT admin- istration $(341 \pm 34 \mathrm{pg} / \mathrm{ml})$, whereas neither THP nor $\mathrm{P}_{4}$ (475 \pm 47 and $567 \pm 128 \mathrm{pg} / \mathrm{ml}$, respectively) significantly altered ACTH levels in ADX/GDX animals.

\section{DISCUSSION}

Previous studies have provided ample evidence that ring-A-reduced steroid metabolites, such as THP, influence vigilance, and anxiety; these steroids have therefore been presumed to have stress-protective properties (Purdy et al. 1991; Paul and Purdy 1992). The present results confirm this view by demonstrating, for the first time, that the stress-protective action of THP also involves a diminution of the endocrine secretory response to emotional stress. Our previous finding (Patchev et al. 1994a) that THP affects the biosynthesis and release of the major secretagogue of $\mathrm{ACTH}, \mathrm{CRH}$, together with the present observation that THP influences the gene transcription of AVP in a neuronal population involved in the initiation of the neuroendocrine response to stress, point to the hypothalamus as a target of THP actions; the possibility that the pituitary may also be a target of THP cannot be excluded at this stage. In view of previous (Herman et al. 1986) and recent (Landgraf et al. 1995) evidence for the involvement of AVP in anxiogenesis, the present findings might be implicated in the mechanisms responsible for the anxiolytic action of neurosteroids.

Possible explanations for the discrepancy between THP effects on ACTH secretion upon stress and adrenalectomy may be found when differences in the time points of investigation and steroid pharmacokinetics are considered. Cyclodextrin-solubilized steroids are reportedly released into the circulation in episodic bursts (Taylor et al. 1994) and may, thus, display rapid onset effects (cf., stress paradigm), whereas the rather

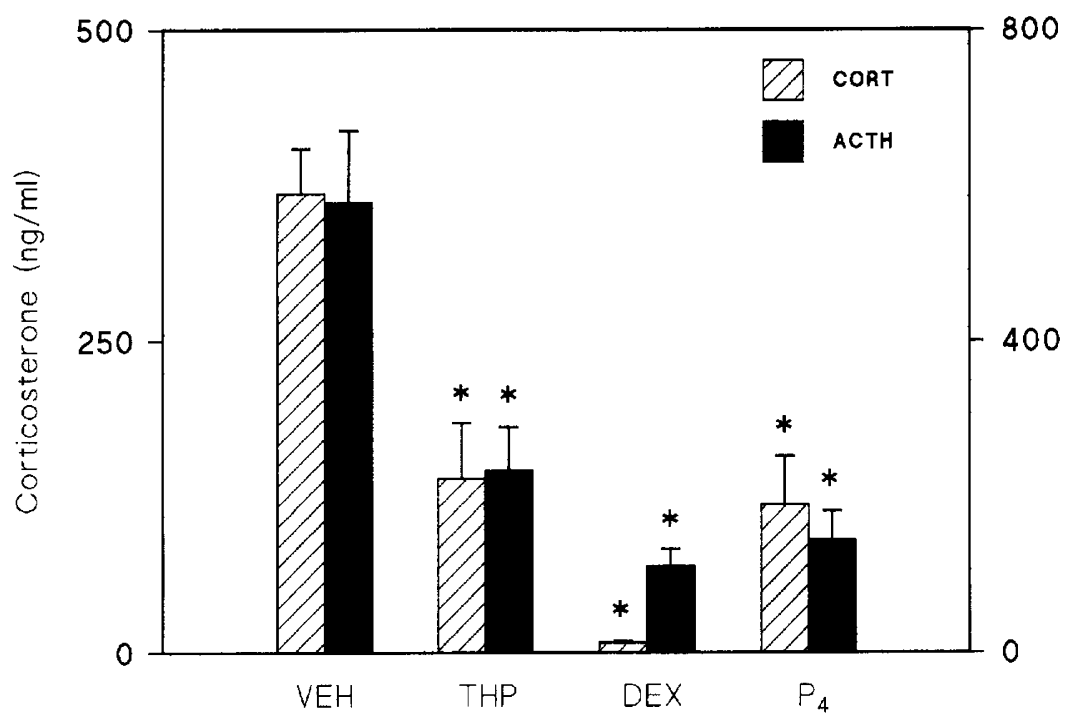

Figure 2. Corticosterone (hatched bars) and ACTH (solid bars) levels 30 minutes after acute emotional stress in rats pretreated with either vehicle (VEH) or different steroids; asterisks denote significant differences compared with the VEH-treated group; each bar represents mean \pm SEM of four to five individuals. 


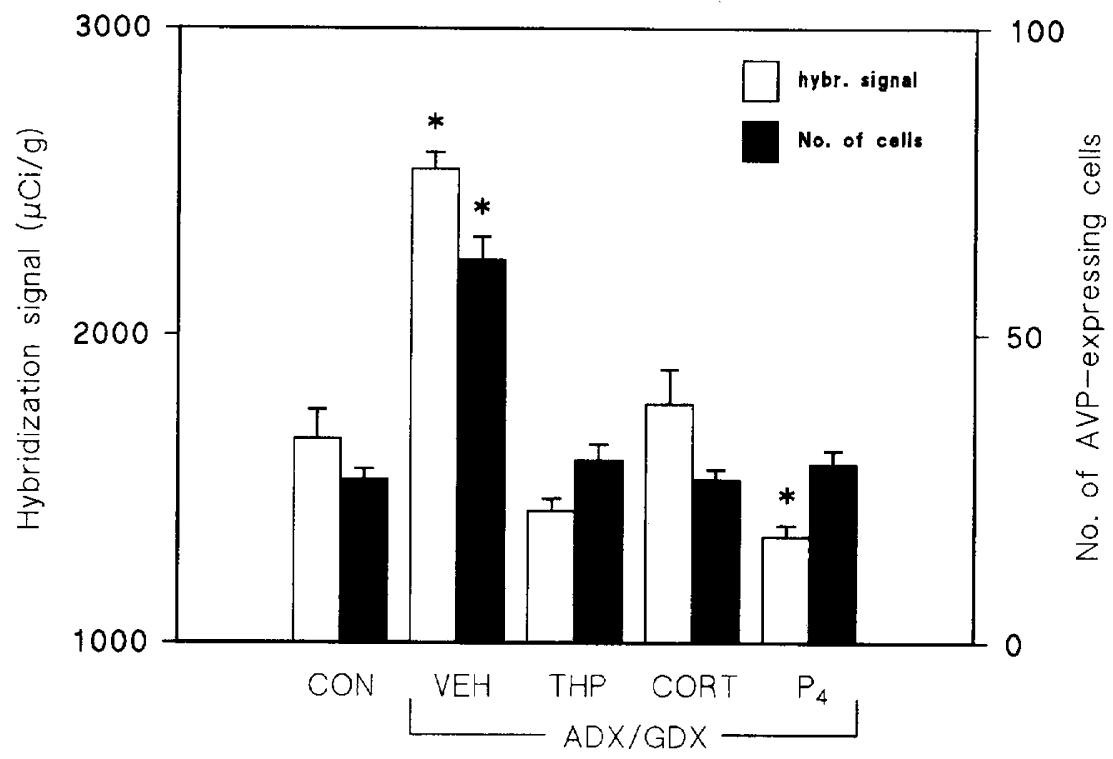

Figure 3. Hybridization signal for AVP mRNA (open bars) and number of AVP-expressing cells (solid bars) in the ventromedial subdivision of the PVN in sham-operated (CON) and ADX/ GDX rats receiving either vehicle or steroid treatment; asterisks indicate significant differences from the CON group.

steady delivery rates from oleous preparations may be insufficient to significantly affect the release of ACTH in ADX/GDX rats. Although THP effects on vigilance were not specifically tested for, the possibility that THP might interfere with the perception of stress might also be considered as an alternative explanation.

The results of several investigations have suggested the THP and other chemically related compounds (e.g., $5 \alpha$-hydroxylated corticosterone derivatives) do not bind to intracellular receptors, thus failing to display the prerequisite for direct interaction with the genome, i.e., binding of an activated receptor to DNA (Gee et al. 1988; Purdy et al. 1991; Baulieu 1992). However, in this and previous studies (Patchev et al. 1994a), we demonstrated that THP administration in vivo results in significant changes in the transcription of several steroidresponsive neuropeptide-encoding genes, with THP displaying effects that resemble those of the typical glucocorticoid CORT, and also (in the case of AVP) of progesterone; chronic administration of $\mathrm{P}_{4}$ results in decreased AVP mRNA levels in the PVN but fails to alter $\mathrm{CRH}$ gene transcription in this nucleus (V.K. Patchev and O.F.X. Almeida, unpublished observations). These findings strengthen the view that neurosteroids may influence gene expression and indicate that the major secretagogues of $\mathrm{ACTH}, \mathrm{CRH}$ and AVP, are potential targets of these actions of THP.

The hippocampal corticosteroid receptors (MR and GR) are crucial components of the circuitry that regulates the secretory activity of the HPA axis. Although the two receptor types display different affinities for glucocorticoids (Reul and De Kloet 1985), their gene expression and binding characteristics in the hippocampus are promptly altered by changes in circulating cor-

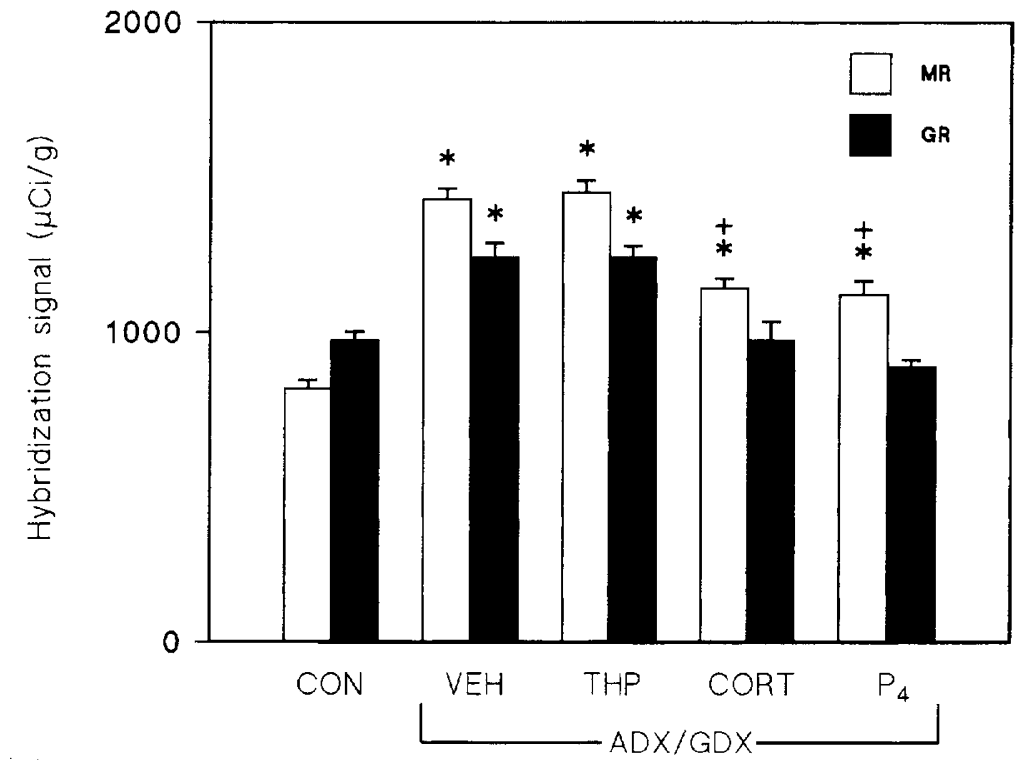

Figure 4. Hybridization signal for MR (open bars) and GR mRNA (solid bars) in the hippocampus; abbreviations as in Figure 2; asterisks and crosses denote significant differences as compared to sham-operated (CON) and vehicle-injected ADX/GDX rats, respectively. 
ticosteroid levels (Spencer et al. 1991; Herman 1993; Patchev et al. 1994b). In agreement with those observations, this study reports that removal of the adrenals and gonads significantly increases MR and GR mRNA levels in the hippocampus. The ADX/GDX-induced up-regulation of MR and GR mRNA levels in the hippocampus was significantly attenuated by supplementation with either CORT or $\mathrm{P}_{4}$. In view of the glucocorticoid-like actions of THP on the gene expression of CRH and AVP, it is striking that this neurosteroid failed to affect the transcription of genes encoding MR and GR in the hippocampus. This observation suggests that the effects of THP on glucocorticoid-responsive genes in the brain are characterized by a certain degree of specificity with regard to both substrate (e.g., neuropeptides vs corticosteroid receptors) and anatomical structure (AVP mRNA in different hypothalamic nuclei).

The mechanisms through which THP exerts its transcriptional effects remain to be elucidated. It is however pertinent to note that: (1) in vitro studies have suggested that progesterone receptors might mediate these actions of THP after intracellular oxidation of this compound to dihydroprogesterone (Rupprecht et al. 1993), and (2) activation of $\mathrm{GABA}_{\mathrm{A}}$ binding sites might also result in altered transcription of neuropeptide-encoding genes (Loeffler et al. 1986; Majzoub et al. 1993). Both explanations may apply to the effects of THP on CRH and AVP mRNA levels in the hypothalamus where neuroendocrine regulation is influenced by both progesterone- and GABA-receptor-mediated mechanisms. However, the hippocampus, which is also amply endowed with $\mathrm{GABA}_{\mathrm{A}}$ receptors (Silviotti and Nistri 1991), failed to respond to THP treatment, at least in terms of altered transcription of MR and GR genes. Site-specific heterogeneity in the subunit composition of $\mathrm{GABA}_{\mathrm{A}}$ receptors (Wisden et al. 1992) may account for the poor efficacy of the allosteric $\mathrm{GABA}_{\mathrm{A}}$ agonist THP in the hippocampus. On the other hand, several speculations may be made regarding the possibility that the genomic effects of THP are mediated through activation of progesterone receptors. First, progesterone receptor densities are lower in this structure compared with those in the hypothalamus (MacLusky et al. 1980; Parsons et al. 1982). Second, conversion of THP to dihydroprogesterone (apparently the biologically active neurosteroid-derived ligand of the progesterone receptor; cf., Rupprecht et al. 1993) in the hippocampus may not be adequate for the production of relevant concentrations of dihydroprogesterone; however, the physiological significance of this process in vivo remains to be established. Third, administration of progesterone itself may result in the generation of steroid $\mathrm{GABA}_{\mathrm{A}}$-ergic agonists and thus, the possibility of dual actions of exogenous progesterone should not be discounted at this stage. Finally, the co-presence of different types of steroid hormone receptors in the hippocampus, and the capacity of these re- ceptors to act on overlapping sets of genes (Arriza et al. 1988), either separately or through the formation of heterodimers (Trapp et al. 1994), implies a high degree of complexity in the regulation of steroid-responsive genes in this structure and, because steroid hormone receptors act in concert with several other transcription factors, the presence or absence of the latter in the structure of interest may significantly influence the magnitude of steroid-mediated effects (Meyer et al. 1989).

In summary, this study indicates that the neurosteroid THP attenuates the endocrine response to stress and affects the gene transcription of AVP in the PVN in a pattern similar to that seen with glucocorticoids and $\mathrm{P}_{4}$. However, unlike CORT and $\mathrm{P}_{4}$, THP failed to influence the transcription of genes encoding corticosteroid receptors in the hippocampus. These results are largely supportive of the hypothesis that certain ring-A-reduced steroid derivatives may act as endogenous suppressors of the stress response (cf., Purdy et al. 1991) and document a dichotomy in the effects of THP upon neural substrates, subserving neuroendocrine and behavioral adaptation. However, because the changes described herein were induced by exogenously administered neurosteroids, further evidence is needed to ascertain that endogenously produced neurosteroids act in a similar fashion under physiological conditions.

\section{ACKNOWLEDGMENTS}

This study was supported by the Max Planck Society and the Deutsche Forschungsgemeinschaft (SFB 220/TP C-8). V. K. Patchev is the recipient of a research award from the Theodore and Vada Stanley Foundation.

\section{REFERENCES}

Antoni FA (1993): Vasopressinergic control of pituitary adrenocorticotropin secretion comes of age. Front Neuroendocrinol 14:76-122

Arriza JL, Simerly WB, Swanson LW, Evans RM (1988): The neuronal mineralocorticoid receptor as a mediator of the glucocorticoid response. Neuron 1:887-900

Baulieu E-E (1992): Neurosteroids: An overview. In Biggio G, Concas A, Costa E (eds), GABAergic Synaptic Transmission. New York, Raven Press, pp 1-16

Bitran D, Hilvers RJ, Kellogg CK (1991): Anxiolytic effects of $3 \alpha$-hydroxy-5 $\alpha(\beta)$-pregnan-20-one: Endogenous metabolites of progesterone that are active at the $\mathrm{GABA}_{\mathrm{A}}$ receptor. Brain Res 561:157-161

Brady LS, Smith M, Gold PW, Herkenham M (1990): Altered expression of hypothalamic neuropeptide mRNA in food-restricted and food-deprived rats. Neuroendocrinology 52:441-447

Castrén M, Patchev VK, Almeida OFX, Holsboer F, Trapp T, Castrén E (1995): Regulation of rat mineralocorticoid 
receptor expression in neurons by progesterone. Endocrinology 136:3800-3806

Chao HM, Choo PH, McEwen BS (1989): Glucocorticoid and mineralocorticoid receptor mRNA expression in rat brain. Neuroendocrinology 50:365-371

Davis LG, Arentzen R, Reid JM, Manning RW, Wolfson B, Lawrence KL, Baldino F Jr (1986): Glucocorticoid sensitivity of vasopressin mRNA levels in the paraventricular nucleus of the rat. Proc Natl Acad Sci USA 83:11451149

Gee KW, Bolger MB, Brinton RE, Coirini H, McEwen BS (1988): Steroid modulation of the chloride ionophore in the rat brain: Structure-activity requirements, regional dependence and mechanisms of action. J Pharmacol Exp Ther 246:803-812

Gillies GE, Linton EA, Lowry PJ (1982): Corticotropin releasing activity of the new CRF is potentiated several times by vasopressin. Nature 299:355-357

Herman JP (1993): regulation of adrenocorticosteroid receptor mRNA expression in the central nervous system. Cell Mol Neurobiol 13:349-371

Herman IP, Thomas GJ, Gash DM (1986): Behavioral characteristics of Roman high avoidance rats homozygous for diabetes insipidus (RHA:di/di). Behav Brain Res 20:2738

Herman JP, Schaefer MK-H, Young EA, Thompson R, Douglass J, Akil H, Watson SJ (1989): Evidence for hippocampal regulation of neuroendocrine neurons of the hypothalamo-pituitary-adrenocortical axis. J Neurosci 9:3072-3082

Ivell R, Richter D (1984): Structure and comparison of the oxytocin and vasopressin genes from rat. Proc Natl Acad Sci USA 81:2006-2010

Kavaliers M, Wiebe JP (1987): Analgesic effects of the progesterone metabolite, $3 \alpha$-hydroxy-5 $\alpha$-pregnan-20one, and possible modes of action in mice. Brain Res 415:393-398

Landgraf R, Gerstberger R, Montkowski A, Probst JC, Wotjak CT, Holsboer F, Engelmann M (1995): Vasopressin receptor antisense oligodeoxynucleotide into septum reduces vasopressin binding, social discrimination abilities, and anxiety-related behavior in rats. J Neurosci $15: 4250-4258$

Loeffler JP, Demeneix BA, Pittius CW, Kley N, Haegele KD, Höllt V (1986): GABA differentially regulates the gene expression of proopiomelanocortin in rat intermediate and anterior pituitary. Peptides 7:253-258

MacLusky NJ, Lieberburg I, Krey LC, McEwen BS (1980): Progestin receptors in the brain and pituitary of the bonnet monkey (Macaca radiata): Differences between the monkey and the rat in the distribution of progestin receptors. Endocrinology 106:185-191

Majewska MD, Harrison NL, Schwartz RD, Barker JL, Paul SM (1986): Steroid hormone metabolites are barbituratelike modulators of the GABA receptor. Science 232:1004-1007

Majzoub JA, Emanuel R, Adler G, Martinez C, Robinson B, Wittert G (1993): Second messenger regulation of mRNA for corticotropin-releasing factor. In Chadwick DJ, Marsh J, Ackrill K (eds), Corticotropin-Releasing Factor. Chichester, UK, John Wiley \& Sons, pp 30-43
McEwen BS, Brinton RE (1987): Neuroendocrine aspects of adaptation. Prog Brain Res 72:11-26

Meyer ME, Gronemeyer H, Turcotte B, Bocquel MT, Tasseet D, Chambon P (1989): Steroid hormone receptors compete for factors that mediate their enhancer function. Cell 57:433-442

Miesfeld R, Rusconi S, Godowski PJ, Maler BA, Okret S, Wikström AC, Gustafsson J-Ä, Yamamoto KR (1986): Genetic complementation of a glucocorticoid receptor deficiency by expression of cloned receptor cDNA. Cell 46:389-399

Parsons B, Rainbow TC, MacLusky NJ, McEwen BS (1982): Progestin receptor levels in rat hypothalamic and limbic nuclei. J Neurosci 2:1446-1452

Patchev VK, Shoaib M, Holsboer F, Almeida OFX (1994a): The neurosteroid tetrahydroprogesterone counteracts corticotropin-releasing hormone-induced anxiety and alters the release and gene expression of corticotropinreleasing hormone in the rat hypothalamus. Neuroscience 62:265-271

Patchev VK, Brady LS, Karl M, Chrousos GP (1994b): Regulation of HSP90 and corticosteroid receptor mRNA by corticosterone in vivo. Mol Cell Endocrinol 103:57-64

Paul SM, Purdy RH (1992): Neuroactive steroids. Fed Proc Am Soc Exp Biol 6:2311-2322

Puia G, Santi MR, Vicini S, Pritchett DB, Purdy RH, Paul SM, Seeburg PH, Costa E (1990): Neurosteroids act on recombinant human GABA receptors. Neuron 4:759765

Purdy RH, Morrow AL, Moore PH Jr, Paul SM (1991): Stressinduced elevations of $\gamma$-aminobutyric acid type A receptor-active steroids in the rat brain. Proc Natl Acad Sci USA 88:4553-4557

Reul JMHM, De Kloet ER (1985): Two receptor systems for corticosterone in rat brain: Microdistribution and differential occupation. Endocrinology 117:2505-2511

Reul JMHM, Pearce PT, Funder JW, Krozowski ZS (1989): Type I and type II corticosteroid gene expression in the rat: Effect of adrenalectomy and dexamethasone administration. Mol Endocrinol 3:1674-1680

Rupprecht R, Reul JMHM, Trapp T, van Steensel B, Wetzel C, Zieglgänsberger W, Damm K, Holsboer F (1993): Progesterone receptor mediated effects of neurosteroids. Neuron 11:523-530

Sapolsky RM, Armanini MP, Packan DR, Sutton SW, Plotsky PM (1990): Glucocorticoid feedback inhibition of adrenocorticotropic hormone secretagogue release. Neuroendocrinology 51:328-336

Sawchenko PE (1987): Adrenalectomy-induced enhancement of CRF and vasopressin immunoreactivity in parvocellular neurosecretory neurons: Anatomic, peptide, and steroid specificity. J Neurosci 7:1093-1106

Sawchenko PE, Swanson LW (1993): The organization of forebrain afferents to the paraventricular and supraoptic nuclei of the rat. J Comp Neurol 218:121-144

Sawchenko PE, Imaki T, Vale W (1992): Co-localization of neuroactive substances in the endocrine hypothalamus. In Chadwick DJ, March J (eds), Functional Anatomy of the Neuroendocrine Hypothalamus. Chichester, UK, John Wiley \& Sons, pp 16-30 
Silviotti L, Nistri A (1991): GABA receptor mechanisms in the central nervous system. Prog Neurobiol 36:35-92

Spencer RL, Miller AH, Stein M, McEwen BS (1991): Corticosterone regulation of type I and type II adrenal steroid receptors in brain, pituitary, and immune tissue. Brain Res 549:236-246

Taylor GT, Scherrer J, Weiss J, Pitha J (1994): Endocrine interactions: Adrenal steroids and precursors. Am J Physiol 266:E676-E681

Trapp T, Rupprecht R, Castrén M, Reul JMHM, Holsboer F (1994): Heterodimerization between mineralocorticoid and glucocorticoid receptor: A new principle of glucocorticoid action in the CNS. Neuron 13:1-20

Whitfield HJ Jr, Brady LS, Smith MA, Mamalaki E, Fox R, Herkenham M (1990): Optimization of cRNA probe in situ hybridization methodology for localization of glucocorticoid receptor $\mathrm{mRNA}$ in rat brain: A detailed protocol. Cell Mol Neurobiol 10:145-157

Wisden W, Laurie DJ, Monyer H, Seeburg PH (1992): The distribution of $13 \mathrm{GABA}_{A}$ receptor subunit mRNAs in the rat brain. I. Telencephalon, diencephalon, mesencephalon. J Neurosci 12:1040-1062 